\title{
California TRV-based VIGS vectors mediate gene silencing at elevated temperatures but with greater growth stunting
}

\author{
Jamilur Rahman ${ }^{1,2}$, Ian T. Baldwin ${ }^{1}$ and Klaus Gase ${ }^{1 *}$
}

\begin{abstract}
Background: Tobacco rattle virus (TRV) based virus-induced gene silencing (VIGS), a widely used functional genomics tool, requires growth temperatures typically lower than those of the plant's native environment. Enabling VIGS under native conditions in the field according to applicable safety regulations could be a revolutionary advance for ecological research.

Results: Here, we report the development of an enhanced thermal tolerant VIGS vector system based on a TRV California isolate. cDNA clones representing the whole viral genome were sequenced and used to construct separate binary plant transformation vectors for functional elements of RNA1 (6765 nt) and RNA2 (3682 nt). VIGS of target genes was induced by transient transformation of the host plant with both vectors or by treating the host plant with sap from already VIGS induced plants. In Nicotiana attenuata the silencing efficiency of the PDS (phytoene desaturase) gene was $90 \%$ at $28^{\circ} \mathrm{C}$ and $78 \%$ at $30^{\circ} \mathrm{C}$. Silencing at these temperatures was more prominent and durable than silencing induced by the widely used TRV PpK20-based pBINTRA6/pTV00 system, but was associated with a viral phenotype. Differences in the suppressor protein and RNA dependent RNA polymerase sequences between the TRV California isolate and PpK20 may be the reason for their different thermal tolerance.
\end{abstract}

Conclusions: The new TRV California-based VIGS vectors induce gene silencing in Nicotiana attenuata at higher temperatures than the existing pBINTRA6/pTV00 vector system, but cause greater growth defects. The new vector system opens up an avenue to study genes functions in planta under field conditions.

Keywords: Allene oxide cyclase (AOC), Higher temperature, Phytoene desaturase (PDS), Tobacco rattle virus (TRV), Virusinduced gene silencing (VIGS), Nicotiana attenuata

\section{Background}

The manipulation of gene expression represents the gold standard for the proof of gene function in many model organisms. Virus-induced gene silencing (VIGS), a transient form of post-transcriptional gene silencing, has emerged as an extremely powerful functional genomics tool for knocking down the expression of target genes in

\footnotetext{
*Correspondence: gase@ice.mpg.de

1 Department of Molecular Ecology, Max Planck Institute for Chemical

Ecology, Hans-Knoell-Str. 8, 07745 Jena, Germany

Full list of author information is available at the end of the article
}

plants [1-3]. VIGS uses viral vectors harboring a target gene fragment to produce dsRNA which triggers RNAmediated silencing of the target gene. Transient VIGS is a simple, cost-effective and considerably less time-consuming method to manipulate gene expression for the analysis of gene function than the classical stable transformation $[4,5]$.

TRV (tobacco rattle virus)-based VIGS has been utilized to effectively manipulate the expression of genes in many important model plant species including Arabidopsis (Arabidopsis thaliana), Nicotiana spp., Tomato (Solanum lycopersicum), Cotton (Gossypium arboreum), 
Petunia hybrida, etc. [6]. TRV-based VIGS has proven the most effective method because TRV has several distinct advantages over other viruses developed for VIGS: relatively mild symptoms of infection, infection of large patches of neighboring cells, migration to growing meristems and thus efficiently into new tissues in all parts of the plant $[2,3,7]$.

TRV is a member of the genus Tobravirus in the family of Virgaviridae and has a bipartite, positive sense single stranded RNA genome (RNA1 and RNA2) [8]. RNA1 and RNA2 are encapsidated separately into tubular, rigid, rod-shaped particles. The RNA1 encoded-proteins are sufficient for replication and movement of the virus within the host plant, while RNA2 encodes proteins for virion formation and nematode-mediated transmission [9]. RNA1 encodes four open reading frames (ORFs) for proteins with predicted molecular weights of 134 and $194 \mathrm{kDa}$ (replicase proteins), $29 \mathrm{kDa}$ (movement protein), and $16 \mathrm{kDa}$ (cysteine-rich protein, a silencing suppressor protein) [10]. RNA1 can replicate and move systemically without RNA2. RNA2 encodes three proteins (coat protein and two non-structural proteins, $29.4 \mathrm{kDa}$ and $32.8 \mathrm{kDa})$ [11].

Genomic diversity analysis of different TRV isolates revealed that the RNA1 genome is well-conserved among the different strains of TRV. At the nucleotide level, 92-99\% similarity is found among different European and American TRV isolates [12]. In contrast to RNA1, RNA2 molecules in various tobravirus isolates show considerable differences in size and composition [13]. RNA2 from different TRV isolates has little nucleotide sequence similarity, for example, TRV Michigan isolate shares only $32-52 \%$ identity with European isolates [12]. Thus, the RNA2 genome is highly variable in nature, which results in numerous serotypes and TRV virus strains [14]. This variability of RNA2 might be due to recombination among tobraviruses $[9,15]$.

A TRV-based VIGS vector system was first described by Ratcliff et al. (2001) [1], afterwards Liu et al. (2002) [16] further modified the vectors. For constructing the first TRV-based VIGS vectors, cDNA from RNA1 of strain PpK20 (Paratrichodorus pachydermus Kinshaldy-20) containing the ORFs for the RNA-dependent RNA polymerase (RdR), the $29 \mathrm{kDa}$ and the $16 \mathrm{kDa}$ proteins, was placed between the Cauliflower Mosaic Virus (CaMV) 35S promoter and terminator. cDNA from RNA2 encoding the coat protein was placed between a CaMV $35 \mathrm{~S}$ promoter and the nopaline synthase terminator. For cloning the target gene sequences a multiple cloning site was introduced downstream from the coat protein gene. The resulting TRV vectors were designated pBINTRA6 and pTV00, respectively [1].
Plant growth conditions such as temperature, relative humidity and age of the inoculated plants, have profound effects on the efficiency and uniformity of VIGS as well as on spread of gene silencing [17]. Among these factors, temperature plays the most critical role and directly influences T-DNA insertion frequency, generation of primary and secondary small interfering RNAs (siRNAs) and spread of the siRNAs to distal organs [18-24]. Depending on plant species, robust TRV-based VIGS occurs at growth temperatures between $19^{\circ} \mathrm{C}$ and $25^{\circ} \mathrm{C}$ $[6,7]$. The optimal growth temperatures for robust silencing after VIGS inoculation are $20-22^{\circ} \mathrm{C}$ for Arabidopsis [25], Nicotiana benthamiana [26], Nicotiana attenuata $[2,3]$ and Nicotiana tabacum [27], $23-25^{\circ} \mathrm{C}$ for cotton [28] and $24^{\circ} \mathrm{C}$ for pepper (Capsicum annuum) [29].

Experimental analyses in the ecological model plant $N$. attenuata, which originates from the Great Basin Desert in the southwest of the United States, revealed that a growth temperature of $22^{\circ} \mathrm{C}$ was optimal to induce the bleaching phenotype by TRV VIGS (pBINTRA6/pTV00 vectors) [2]. Temperatures both lower than $20^{\circ} \mathrm{C}$ and greater than $24^{\circ} \mathrm{C}$ dramatically reduced the efficiency of silencing (unpublished data). Thus, the available pBINTRA6/pTV00-based TRV-VIGS vectors could not be used as a functional genomics tool for gene silencing in $N$. attenuata grown in the plant's native environment, where higher temperatures (above $25^{\circ} \mathrm{C}$ ) commonly occur. Hence, engineering of greater thermal tolerance into the TRV-based VIGS system would be the first and most important step in developing a viable VIGS-based gene silencing system for field work with the $N$. attenuata system. Developing a VIGS vector system that functions under field conditions would be a "game changer" for ecological research. We assumed that the main technical challenge of this TRV-VIGS system was the thermal tolerance of the utilized TRV strain PpK20. The lower temperature requirement of this strain might be attributed to its geographic origin: PpK20 was collected from Kinshaldy, Scotland [30], where the climate is generally cool and annual average temperature is $10.5^{\circ} \mathrm{C}$ [31].

Developing a more temperature tolerant TRV VIGS vector system enabling gene silencing in the native environment of $N$. attenuata, taking into account applicable safety regulations, would open up a new avenue for analyzing gene function of this model organism and other tropical or subtropical plant species (e.g., Solanaceae, Cucurbitaceae, Poaceae, etc.) under field conditions. Developing such vectors requires a TRV strain with higher thermal tolerance than the currently used TRV PpK20. We hypothesized that TRV isolates collected from places with higher annual average temperatures than Scotland would allow VIGS to be performed 
at higher temperatures than those achieved with the current pBINTR6/pTV00 system.

Here we developed a new VIGS vector system using a TRV isolate collected from coastal California (Santa Barbara County), USA, that was designated TRV California. First, we sequenced the complete TRV California genome consisting of RNA1 and RNA2. In the next step, we constructed a new VIGS vector system based on this genome. We noted the sequence differences between the genomes of TRV California and PpK20 and other TRV isolates. The functional analysis of the new TRV-based VIGS system showed that the vectors induced profound gene silencing (up to 90\%) at higher growth temperatures $\left(28^{\circ} \mathrm{C} / 30^{\circ} \mathrm{C}\right)$ in Nicotiana attenuata, indicating greater thermal tolerance of the new vector system compared to the current vectors, pBINTRA6 and pTV00.

\section{Results}

Isolation and cloning of the complete genomes of RNA1 and RNA2 of TRV California

We amplified the virus from the infected spinach leaf samples [32] by inoculation of the leaves of four host plant species viz. spinach, pepper, $N$. benthamiana and $N$. attenuata. One week after inoculation typical TRV infection symptoms, e.g. blotchy light and dark discoloration of leaf tissue, chlorotic spots and localized necrotic lesions appeared on the leaves of host plants (Figs. 1A, B and S1). To confirm the TRV infection of these plants, we amplified and sequenced diagnostic PCR-fragments of RNA1 cDNA with sizes of $341 \mathrm{bp}$ (Fig. S2A) and $611 \mathrm{bp}$ (Fig. S2B) using TRV RNA1 genome specific primers. A comparison of the obtained sequence with TRV sequences in GenBank confirmed their identity as TRV fragments.

To obtain the whole genome sequences, the full length RNA1 and RNA2 genomes of TRV California strain were reverse transcribed and amplified by PCR using the respective genome specific primers and total RNA from TRV California infected plant samples (Figs. 1D and E). The amplified full-length RNA2 genome was cloned in pCR Blunt II-TOPO. Since a TRV RNA1 protein encoded in the $\mathrm{RdR}$ open reading frame (ORF) is toxic to E. coli [1], it was not possible to clone the full-length cDNA of this RNA. To overcome this problem, we divided the TRV RNA1 cDNA into three fragments, thereby interrupting the RdR ORF. The three fragments $(2.1 \mathrm{~kb}, 3.4 \mathrm{~kb}$ and $1.2 \mathrm{~kb}$ ) were PCR amplified and cloned separately in pJET1.2.

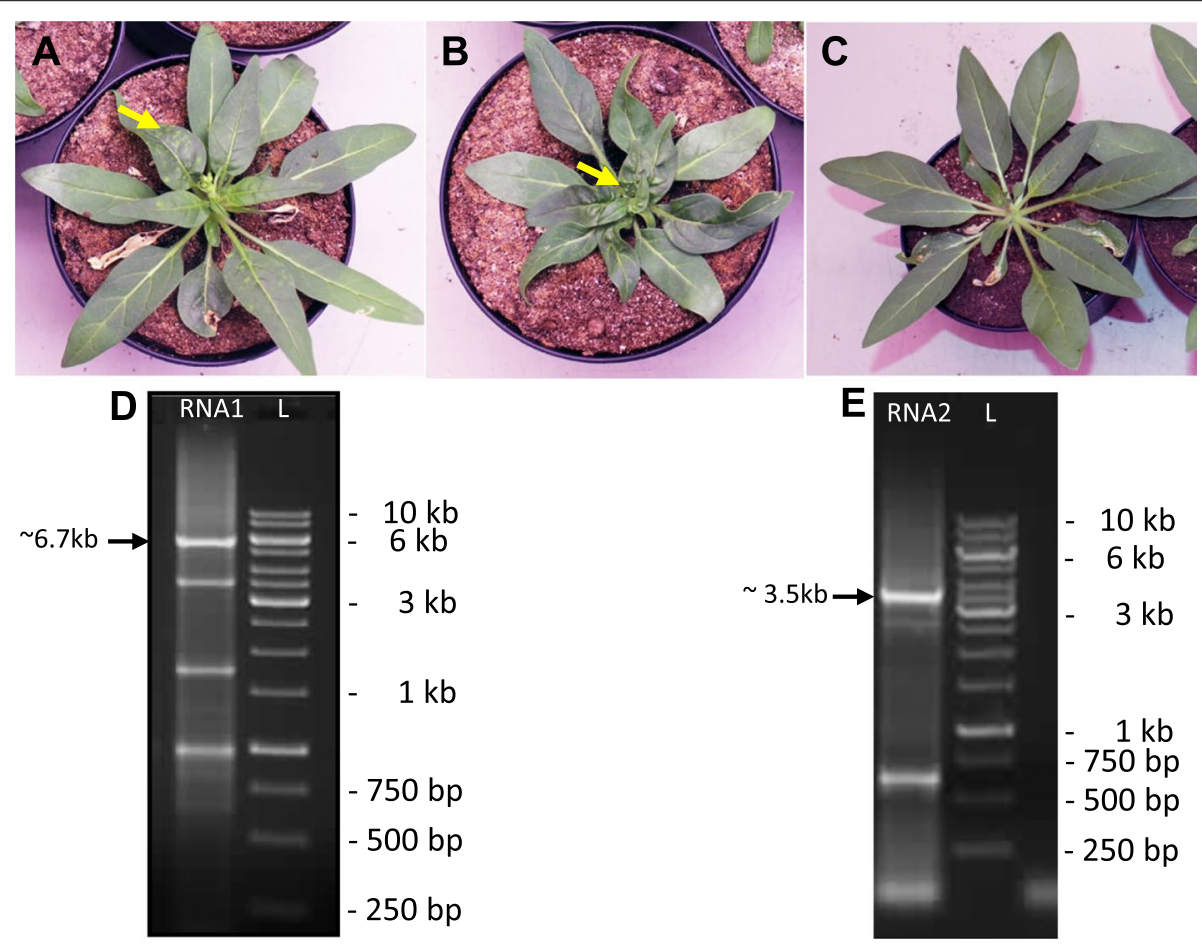

Fig. 1 Isolation of the full length cDNA of the TRV California genomes from infected N. attenuata. A and $\mathbf{B}$ Inoculated plants show the viral symptoms e.g. mottling, localized necrotic lesions, chlorotic spots on the leaves and leaf-deformities in the TRV California inoculated plants. C No such symptoms appeared in the control plants, where only buffer was inoculated. Photographs were taken at $15 \mathrm{dpi}$. The yellow arrows indicate the virus symptoms on leaves. $\mathbf{D}$ and $\mathbf{E} 1 \%$ agarose gel images of PCR amplification of CDNA from full length RNA1 (D, lane RNA1, size 6.6 kb) and RNA2 (E, lane RNA2, 3.5 kb) with TRV California genome specific primers. Lanes 'L' represent the $1 \mathrm{~kb}$ DNA ladder. The gel images are cropped 
We sequenced the full-length TRV California RNA1 and RNA2 genomes from the cloned TRV fragments. The genome organization of TRV California RNA1 and RNA2 was similar to RNA1 and RNA2 described for other TRV isolates $[9,33,34]$.

RNA1 consists of $6765 \mathrm{nt}$ and encodes four putative ORFs of proteins with molecular weights of $134 \mathrm{kDa}$, $194 \mathrm{kDa}, 29 \mathrm{kDa}$, and $16 \mathrm{kDa}$ and $5^{\prime}$ and $3^{\prime}$ non-coding regions (NCR) of $179 \mathrm{nt}$ and $252 \mathrm{nt}$, respectively (Fig. 2A). The ORF designation follows that in MacFarlane (1999) [9] and Crosslin et al. (2010) [12]. The first ORF starts at position 180 and ends with an UGA (opal) stop codon at position $3741 \mathrm{nt}$ (Fig. 2A). It encodes a $134 \mathrm{kDa}$ protein. Read through of this stop codon continues the ORF for further $1557 \mathrm{nt}$ (519 amino acid residues) to encode the $194 \mathrm{kDa}$ protein, the $\mathrm{RdR}$. The $134 \mathrm{kDa}$ protein comprises the amino terminal portion of the $194 \mathrm{kDa} \mathrm{RdR}$ and contains the helicase and nucleotide-binding motifs. The $29 \mathrm{kDa}$ ORF encodes a putative movement protein [12]. The $16 \mathrm{kDa}$ protein is a small, cysteine-rich RNAi silencing suppressor protein [10].

RNA2 consists of $3682 \mathrm{nt}$ and contains three putative ORFs and $5^{\prime}$ and $3^{\prime}$ NCRs of $522 \mathrm{nt}$ and $568 \mathrm{nt}$, respectively (Fig. 2B). The first ORF encodes the $22.4 \mathrm{kDa}$ putative coat protein of the virus. The second ORF encodes a $37.6 \mathrm{kDa}$ protein and the third ORF codes for a protein of $33.6 \mathrm{kDa}$ (Fig. 2B). Lastly, the $3^{\prime}$ end terminal of RNA2 contains a region that is proposed to originate from the $3^{\prime}$ end of RNA1 of TRV [35].

\section{Phylogenetic analysis of TRV California and PpK20}

To compare the sequence differences in the genomes of TRV California, PpK20 and other TRV isolates, we performed pairwise alignment analysis and constructed phylogenetic trees using the RNA1 and RNA2 genomes of PpK20 and other TRV strains submitted as full-length genomes to the NCBI data base.

The phylogenetic analysis of different RNA1 genomes revealed that the TRV California isolate is positioned in a clade of American isolates separate from European TRV isolates e.g., PpK20 (Scotland), PpO85 (Netherland) (Fig. 3A). The tree shows that the PpK20 isolate, which shares $92.5 \%$ sequence identity with the TRV California strain, is positioned in a clade of out-groups separate from the TRV California isolate (Fig. 3A), suggesting that the isolates are distantly related to each other. However, TRV isolates e.g. Deb57, Mlo7, 11r21, Deb57, Slu24 originating from Poland and isolate Ho originating from Germany were in the same clade as the TRV California strain, but in different clusters (Fig. 3A).

The phylogenetic tree of the RNA2 genomes showed that the American isolates, BM, PmF-12, Cot2, Pallm-3, M1, ORY, OR2 and Umt1 are clustered in the same clade as the TRV California isolate indicating their parallel evolutionary pattern (Fig. 3B). The European isolates, except the PpK20, are grouped in clades different from the TRV California isolate and form different groups in the phylogeny tree (Fig. 3B). The PpK20 strain, which shares 95\% sequence identity with the TRV California strain, was positioned in the same clade as the California isolate, albeit in a different branch of the clade (Fig. 3B).

\section{Construction of a new VIGS vectors system based on TRV California}

To construct the TRV California based VIGS vector system we mainly followed the design of the previously reported pBINTRA6 and pTRV00 vectors based on the TRV PpK20 isolate [1]. We created two separate binary plant transformation vectors for the cDNA of TRV California RNA1 and RNA2 based on pSOL9DEF1

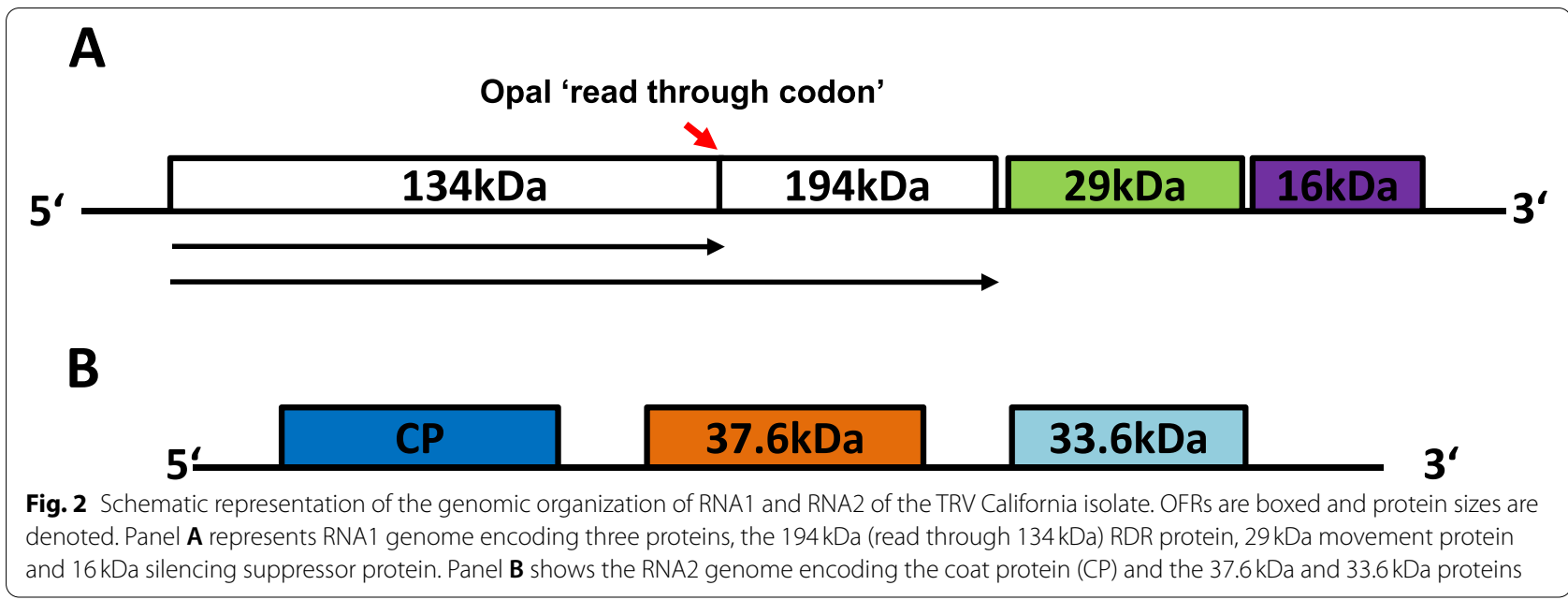



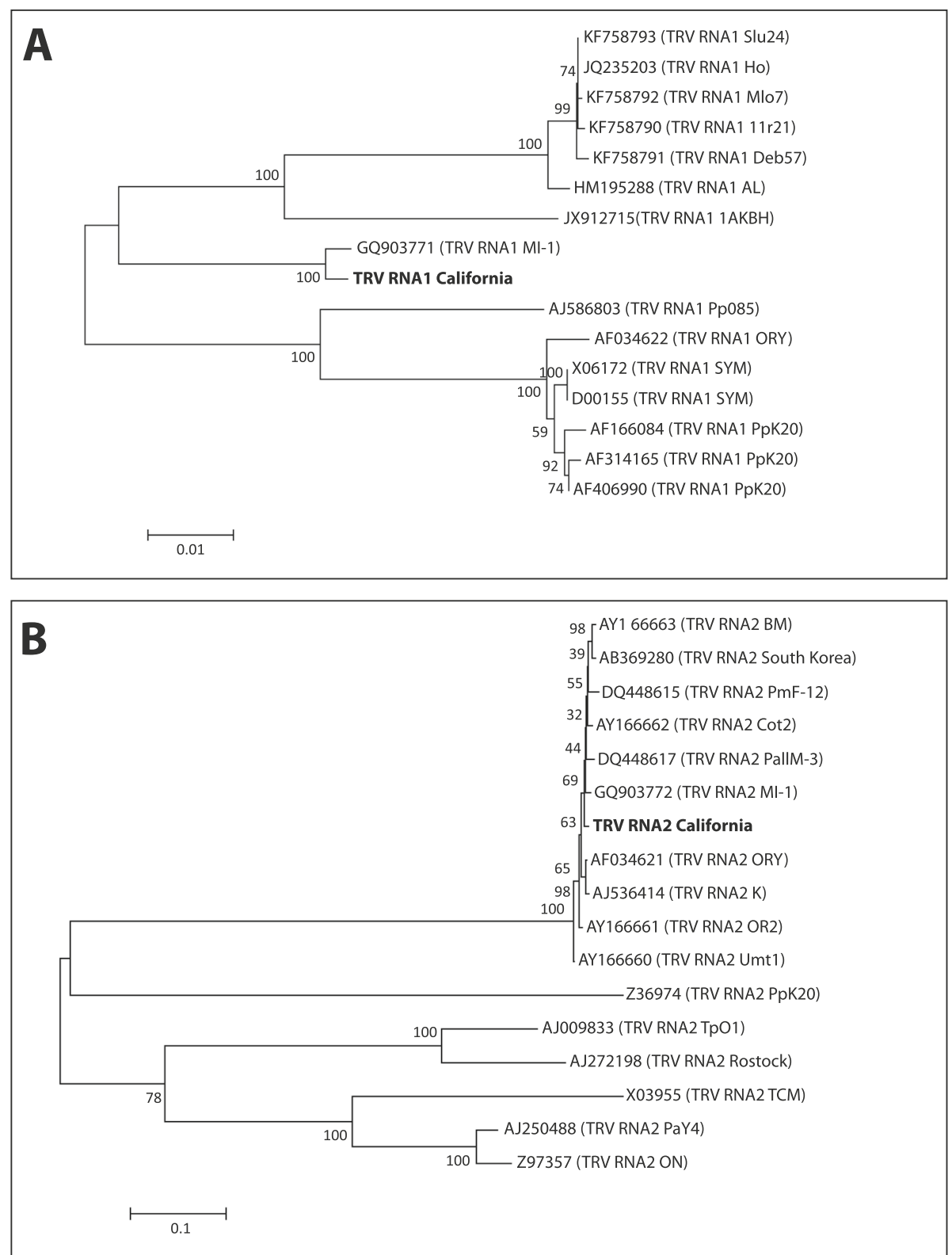

Fig. 3 Phylogenetic analysis of RNA1 and RNA2 genomes of the TRV California isolate. Phylogenetic trees showing the relationship between A) RNA1 genomes of fifteen TRV isolates and RNA1 of the California isolate and B) between RNA2 genomes of sixteen TRV isolates and RNA2 of the California isolate. The nucleotide sequences were aligned using the ClustalW method and the trees were constructed by neighbor-joining method using MEGA version 5 [36]. Numbers close to the nodes indicate bootstrap values and the scale shows 0.1 nucleotide substitutions per site. The deduced nucleotide sequences were retrieved from the NCBI GenBank database

(pTRV-RNA1 and pTRV-RNA2, Fig. 4A and B). The pSOL9 vector backbone has been successfully used before for the stable transformation of $N$. attenuata and carries outside of the T-DNA only the functional elements required for bacterial replication [37].

The pTRV-RNA1 $(14.4 \mathrm{~kb})$ construct contains a fulllength infectious cDNA of California TRV RNA1. The RdR ORF has been interrupted by the insertion of intron
3 of the A. thaliana NIA1 gene for nitrate reductase (GenBank Z19050) to prevent the expression of a protein that is toxic to E. coli [1]. The construct also contains the full length ORFs of the $29 \mathrm{kDa}$ protein (movement protein) and the $16 \mathrm{kDa}$ protein (silencing suppressor protein) of the TRV California strain (Fig. 4A).

In the pTRV-RNA2 $(8.9 \mathrm{~kb})$ construct, the non-essential $37.6 \mathrm{kDa}$ and $33.5 \mathrm{kDa}$ protein genes were removed, 


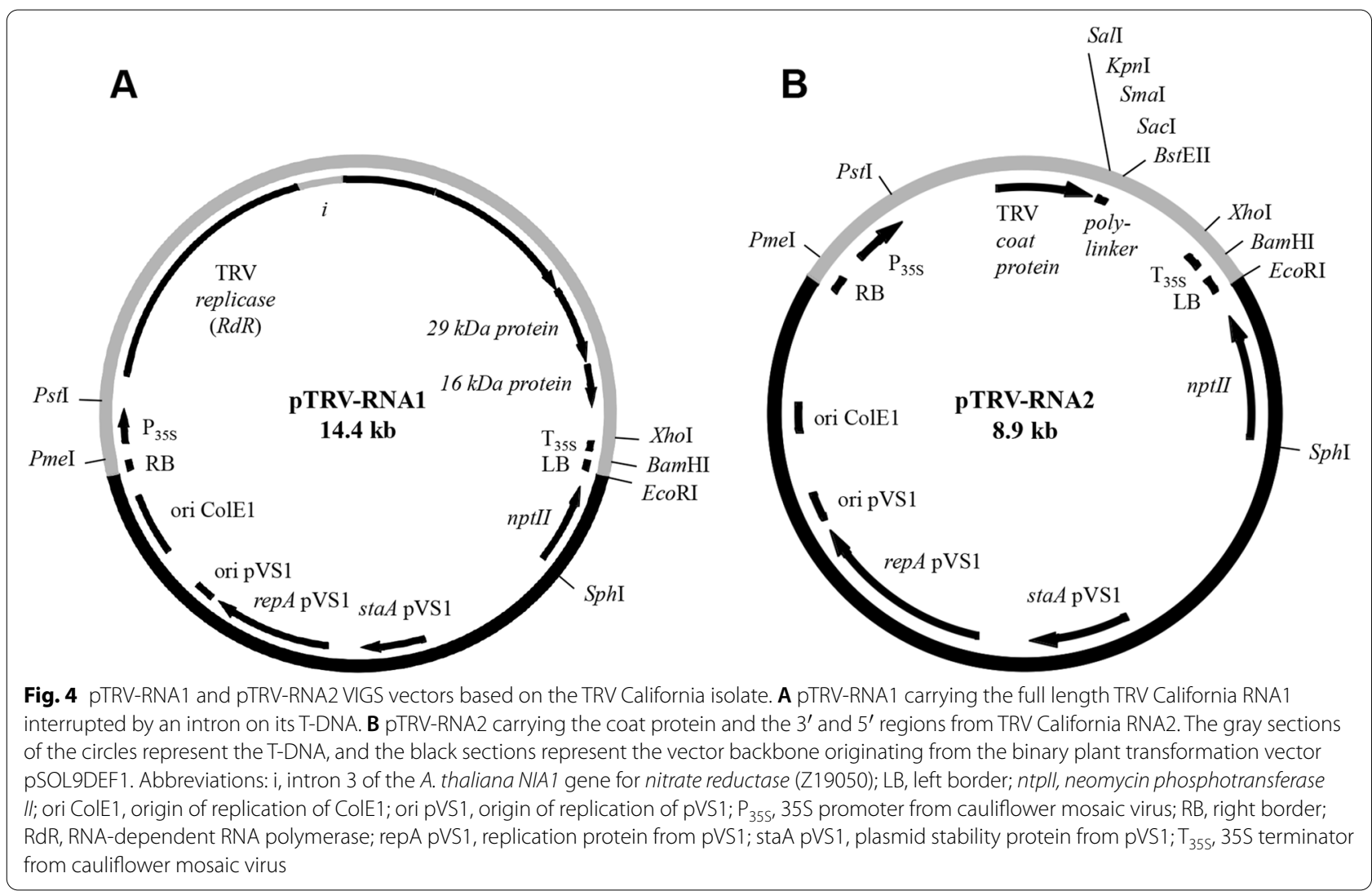

leaving only the $5^{\prime}$ and $3^{\prime}$ untranslated regions and the coat protein (CP) gene of the virus (Fig. 4B). A polylinker has been introduced directly downstream from the coat protein ORF, facilitating the cloning of the target gene fragments.

\section{pTRV-RNA1 and pTRV-RNA2 induce gene silencing} under higher temperature growth conditions $\left(26-30^{\circ} \mathrm{C}\right)$

To test whether the newly developed pTRV-RNA1 and pTRV-RNA2 vectors can be used for VIGS under field conditions, we determined the upper temperature limits of their silencing function. For this, we constructed pTRV2:PDS by cloning a $206 \mathrm{bp}$ fragment of the phytoene desaturase (PDS) gene from $N$. benthamiana in the polylinker of pTRV-RNA2 and again studied bleaching due to PDS silencing in $N$. attenuata.

Initially, we used a growth temperature of $22^{\circ} \mathrm{C}$, as this is the optimal temperature to perform VIGS with the PpK20 derived vectors pBINTRA6 and pTRV00 [3]. The pTRV-RNA1 and pTRV-RNA2:PDS inoculated $N$. attenuata plants showed the bleaching phenotype in the newly emerged leaves at $22^{\circ} \mathrm{C}$ (Figs. 5A and 6A). Bleaching started after $10 \mathrm{dpi}$ and continued until seed set of plants. The quantitative PCR data indicated that $90 \%$ of the PDS transcripts were silenced in the TRV California
VIGS inoculated plants compared to the empty vector (EV) pTRV-RNA2 inoculated control plants (Fig. 6B) at $22^{\circ} \mathrm{C}$. This result indicates that the TRV California derived VIGS vectors are functional when $N$. attenuata is grown at $22^{\circ} \mathrm{C}$. Morphologically, all pTRV-RNA2:PDS and EV inoculated plants were stunted with slow growth compared to non-inoculated WT type plants (Fig. S3).

In the following experiment with vectors pTRV-RNA1 and pTRV-RNA2:PDS, VIGS inoculated $N$. attenuata plants, which were maintained and also inoculated at $22^{\circ} \mathrm{C}$ growth conditions, were moved to different higher temperature conditions, e.g., $26^{\circ} \mathrm{C}, 28^{\circ} \mathrm{C}, 30^{\circ} \mathrm{C}, 32^{\circ} \mathrm{C}$. At 13 dpi the bleaching phenotype appeared in the newly emerged leaves of inoculated plants kept at $26^{\circ} \mathrm{C}, 28^{\circ} \mathrm{C}$, $30^{\circ} \mathrm{C}$ (Figs. 5B-D and S3B-D), but developed into a full bleaching phenotype only in the young emerged leaves of plants maintained at $26^{\circ} \mathrm{C}$ and $28^{\circ} \mathrm{C}$. The bleaching of plants kept at $30^{\circ} \mathrm{C}$ was scattered and concentrated in leaf veins (Fig. $5 \mathrm{D}$ and $\mathrm{S} 3 \mathrm{D}$ ). We repeated the experiments at least three times and obtained similar results (Table S3). About 77 and $73 \%$ of the inoculated plants showed the bleaching phenotype at $26^{\circ} \mathrm{C}$ and $28^{\circ} \mathrm{C}$, respectively, while only 70 and $40 \%$ of the inoculated plants had bleaching symptoms at $22^{\circ} \mathrm{C}$ and $30^{\circ} \mathrm{C}$, respectively (Table S3). Thus, the results revealed that TRV California 

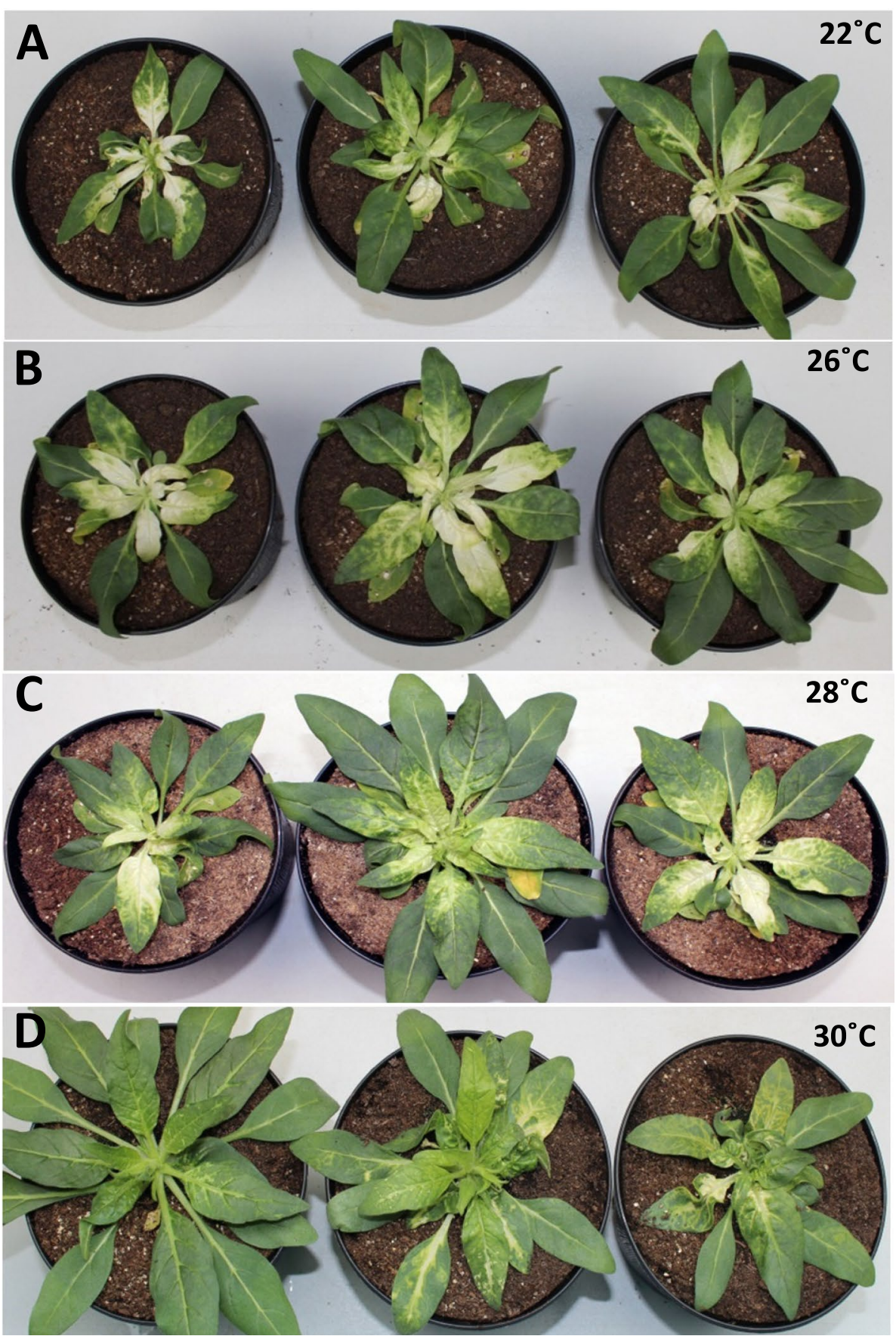

Fig. 5 TRV California vectors induce PDS silencing in N. attenuata. Bleaching phenotype of N. attenuata after PDS silencing induced by pTRV-RNA1 and pTRV-RNA2:PDS at $22^{\circ} \mathrm{C}, 26^{\circ} \mathrm{C}, 28^{\circ} \mathrm{C}$ and $30^{\circ} \mathrm{C}$ growth temperature. The photographs of the plants were taken at $13 \mathrm{dpi}$ (days post inoculation) for $22^{\circ} \mathrm{C}, 26^{\circ} \mathrm{C}, 28^{\circ} \mathrm{C}$ (panels $\mathbf{A}, \mathbf{B}, \mathbf{C}$ ) and at $17 \mathrm{dpi}$ for $30^{\circ} \mathrm{C}$ (panel $\mathbf{D}$ )

derived VIGS vectors induced stronger $P D S$ silencing at $26^{\circ} \mathrm{C}$ and $28^{\circ} \mathrm{C}$ than at $22^{\circ} \mathrm{C}$ and $30^{\circ} \mathrm{C}$.

To quantify the $P D S$ silencing in the inoculated plants, we measured the relative abundance of $P D S$ transcripts in VIGS silenced and EV control plants. We found that $93 \%$ of the $P D S$ transcripts were silenced at $28^{\circ} \mathrm{C}$, while $76 \%$ of the $P D S$ transcripts were silenced at $30^{\circ} \mathrm{C}$ (Fig. $6 \mathrm{~B}$ ). Neither bleaching phenotype nor virus symptoms were found in inoculated plants kept at $32^{\circ} \mathrm{C}$ or higher temperatures (data not shown). 


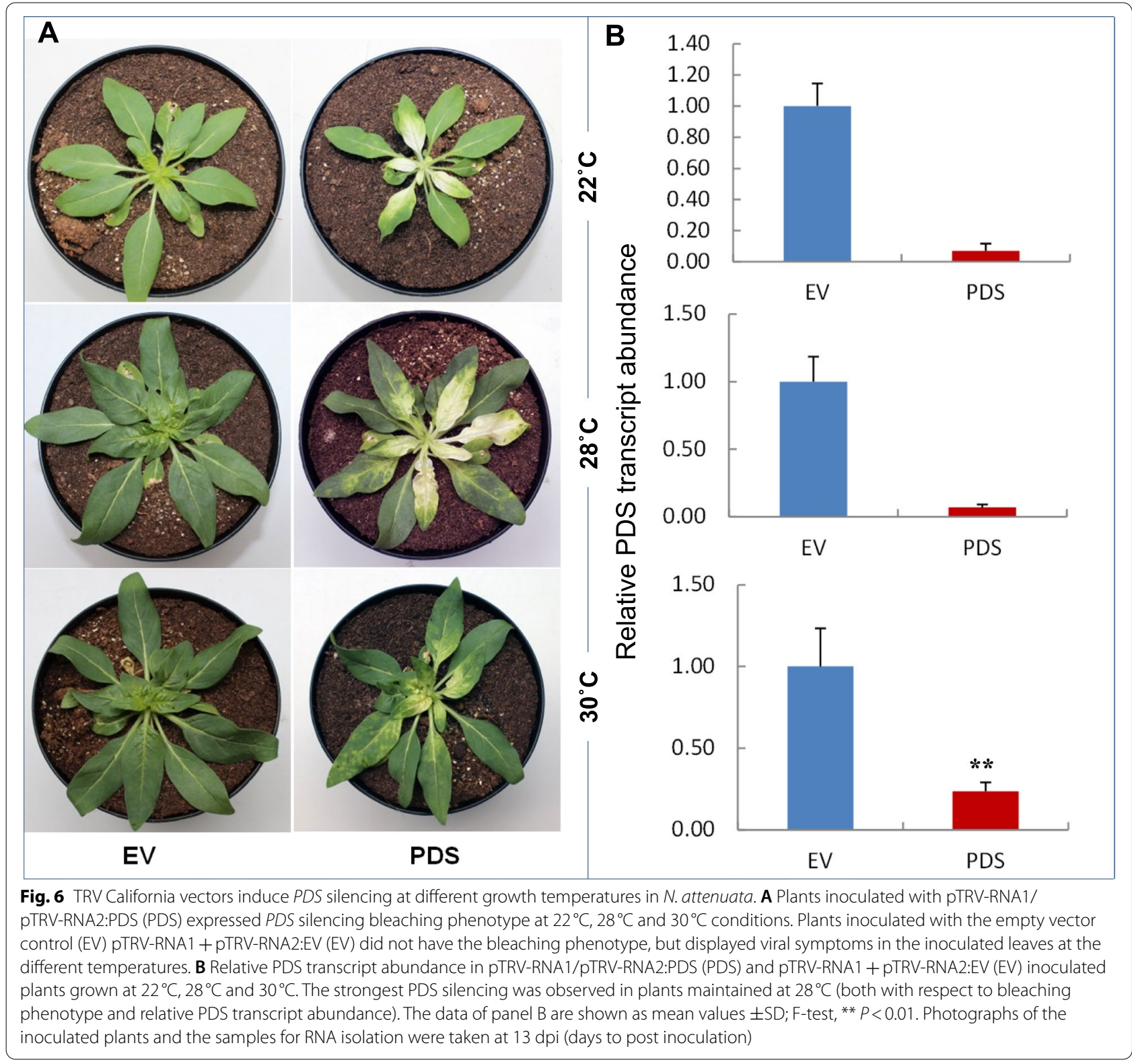

\section{Comparison of silencing efficiency of TRV California and PpK20 derived vectors under higher temperature growth conditions $\left(28-30^{\circ} \mathrm{C}\right)$}

We directly compared the PDS silencing efficiency of the TRV-California (pTRV-RNA1/pTRV-RNA2:PDS) and PpK20 (pBINTRA6/pTVPD) vector systems under relatively high temperature conditions. Both pTRVRNA2:PDS and pTVPD carry the same 206bp target fragment of the phytoene desaturase (PDS) gene from $N$. benthamiana in antisence orientation. Silencing efficiency was always determined relative to the respective EV (pTRV-RNA2 and pTV00) control plants. After inoculation, $N$. attenuata plants were kept at different temperatures, e.g. from $22^{\circ} \mathrm{C}$ to $30^{\circ} \mathrm{C}$, in growth chambers. We found almost similar PDS silencing efficiencies for both vector systems at a growth temperature of $22^{\circ} \mathrm{C}$, as evident by a similar type of photo bleaching phenotype observed in the leaves of the inoculated plants (Fig. 7A). Transcript quantification showed that at $22^{\circ} \mathrm{C}$ almost $90 \%$ of the $P D S$ transcripts were silenced by both vector systems (Fig. 7B). This result indicates that both vectors systems induce profound gene silencing at $22^{\circ} \mathrm{C}$. We observed that $P D S$ gene silencing induced by the PpK20 vector system in $N$. attenuata was reduced under higher temperature conditions, only 67 and $40 \%$ of the PDS transcripts were silenced at $28^{\circ} \mathrm{C}$ and $30^{\circ}$, respectively 
(Fig. 7A and B). In contrast, the TRV California derived VIGS vectors yielded almost 90 and $79 \%$ silencing of the $P D S$ transcripts at $28^{\circ} \mathrm{C}$ and $30^{\circ} \mathrm{C}$, respectively (Fig. 7A and $\mathrm{B})$. The results clearly indicate that the TRV California derived VIGS vector system is more thermal tolerant than the PpK20 derived vector system.

To further examine systemic gene silencing in the newly grown apical leaves of $N$. attenuata, we inoculated plants with the sap of pre-established plants silenced by TRV California and PpK20 vectors and allowed them to grow further until $20 \mathrm{dpi}$. We found that the bleaching phenotype was spreading systemically in the newly emerged apical leaves of TRV California vector sapinoculated plants kept at $28^{\circ} \mathrm{C}$ and $30^{\circ} \mathrm{C}$ (Fig. S4A and B). In plants inoculated with PpK20 vector sap and kept under the same temperature conditions, we observed a weak bleaching phenotype concentrated only in the vein regions of basal leaves (Fig. S4A and B). qPCR quantifications revealed that almost 90 and $84 \%$ of the PDS transcripts were silenced in the TRV California vector sap treated plants, while only 60 and $20 \%$ of the PDS transcripts were silenced in the PpK20 vector sap treated plants kept at $28^{\circ} \mathrm{C}$ and $30^{\circ} \mathrm{C}$, respectively (Fig. 7C).

\section{RNA1 and RNA2 vector swap experiments reveal the significance of TRV RNA1 for temperature tolerance} The TRV California based VIGS vector system is functional at higher temperatures than that based on PpK20. To figure out whether the RNA1 or RNA2 genomes mainly determine the thermal tolerance of both TRV isolates, we conducted RNA1 and RNA2 vector swap experiments in $N$. attenuata and quantified bleaching due to PDS silencing with the mixed PpK20/California TRV vectors (Fig. S5). For PDS silencing, RNA1 vectors pBINTRA6 and pTRV-RNA1 and RNA2 vectors PTVPD and pTRV-RNA2:PDS were used. We found that combining the RNA1 and RNA2 genomes from the two different TRV isolates still results in functional viruses. The vector combination pTRV-RNA1 (TRV California) and pTVPD (PpK20) induced PDS silencing at both $22^{\circ} \mathrm{C}$ and $28^{\circ} \mathrm{C}$, while the vector combination pBINTR6 (PpK20) and pTRV-RNA2:PDS (TRV California) induced PDS silencing only at $22^{\circ} \mathrm{C}$, but not at $28^{\circ} \mathrm{C}$. No bleaching phenotype was observed at $30^{\circ} \mathrm{C}$ in both combinations of the vectors (Fig. S5). Since the TRV California VIGS vectors are still functional at $30^{\circ} \mathrm{C}$, these results suggest, that mainly RNA1 determines the higher temperature tolerance of this isolate, but that RNA2 also contributes to it.

\section{Silencing of the ecologically relevant allene oxide cyclase (AOC) gene in N. attenuata by the TRV California vectors at $28^{\circ} \mathrm{C}$ and $30^{\circ} \mathrm{C}$}

We used the TRV California vector system to silence the ecologically relevant allene oxide cyclase $(A O C)$ gene at higher temperatures in $N$. attenuata. The $A O C$ gene was chosen as it is a single copy gene in the genome of $N$. attenuata and catalyses an essential step in the biosynthesis of the phytohormone jasmonic acid (JA). Silencing $A O C$ blocks the biosynthesis of JA and its derivatives. Jasmonates are important signals in plant stress responses and plant development [38] and mediate many important ecological responses [39]. The expression of the $A O C$ gene is up-regulated after wounding both locally and systemically and after treatment with oral secretion (OS) of herbivores [40]. To silence the $A O C$ gene in $N$. attenuata, we co-inoculated WT plants with pTRV-RNA1 and pTRV-RNA2:AOC or pTRV-RNA1 and pTRV-RNA2 (EV control) and grew them at $28^{\circ} \mathrm{C}$ and $30^{\circ} \mathrm{C}$. To induce the $A O C$ gene, the inoculated plants were treated with OS of Manduca sexta larvae at 13 dpi. Leaf samples for total RNA isolation were harvested $5 \mathrm{~h}$ after OS induction. qPCR with the $A O C$ transcripts from the treated plants maintained at $28^{\circ} \mathrm{C}$ and $30^{\circ} \mathrm{C}$ revealed that 65 and $52 \%$, respectively, of the $A O C$ transcripts were silenced by pTRV-RNA2:AOC relative to the EV control (Fig. 8A and B). Morphologically, the AOC silenced plants had feeble phenotypes compared to the EV inoculated plants.

\section{Discussion}

TRV-based VIGS is very popular as a successful gene knock-down technique. However, the thermal tolerance limit of the current vectors remains the main impediment for its application in diverse plant species and at temperatures above $22^{\circ} \mathrm{C}$ as well as under field conditions. Hence, developing a thermal tolerant TRV based VIGS vector could be valuable for plant species that grow in tropical and sub-tropical habitats and plants growing under climate change conditions. Here, we report a new vector system based on the TRV California isolate that

(See figure on next page.)

Fig. 7 Phytoene desaturase (PDS) silencing efficiency in N. attenuata at different growth temperatures. A Bleaching phenotype of plants inoculated with TRV California (pTRV-RNA1/pTRV-RNA2:PDS; California) and PpK20 (pBINTRA6/pTVPD; PpK20) based VIGS vectors for PDS silencing. B Relative $P D S$ transcript abundance in the same plants compared to empty vector controls (EV). Growth temperatures after inoculation $\left(22^{\circ} \mathrm{C}, 28^{\circ} \mathrm{C}\right.$ and $30^{\circ} \mathrm{C}$ ) are indicated. Pictures and samples for PDS transcript quantification were taken at 13 dpi (days post inoculation). C Relative PDS transcript abundance of plants inoculated with sap from N. attenuata pre-inoculated with the same plasmid combinations as above. Growth temperatures after sap-inoculation $\left(28^{\circ} \mathrm{C}\right.$ and $30^{\circ} \mathrm{C}$ ) are indicated. Samples for PDS transcript quantification were taken from apical leaves at $20 \mathrm{dpi}$. Transcript abundance in $\mathrm{B}$ ) and $\mathrm{C}$ ) is shown as mean values $\pm \mathrm{SD}$ (Student's t-test, ${ }^{*} P<0.05$ and ${ }^{*} P<0.01$ ) 


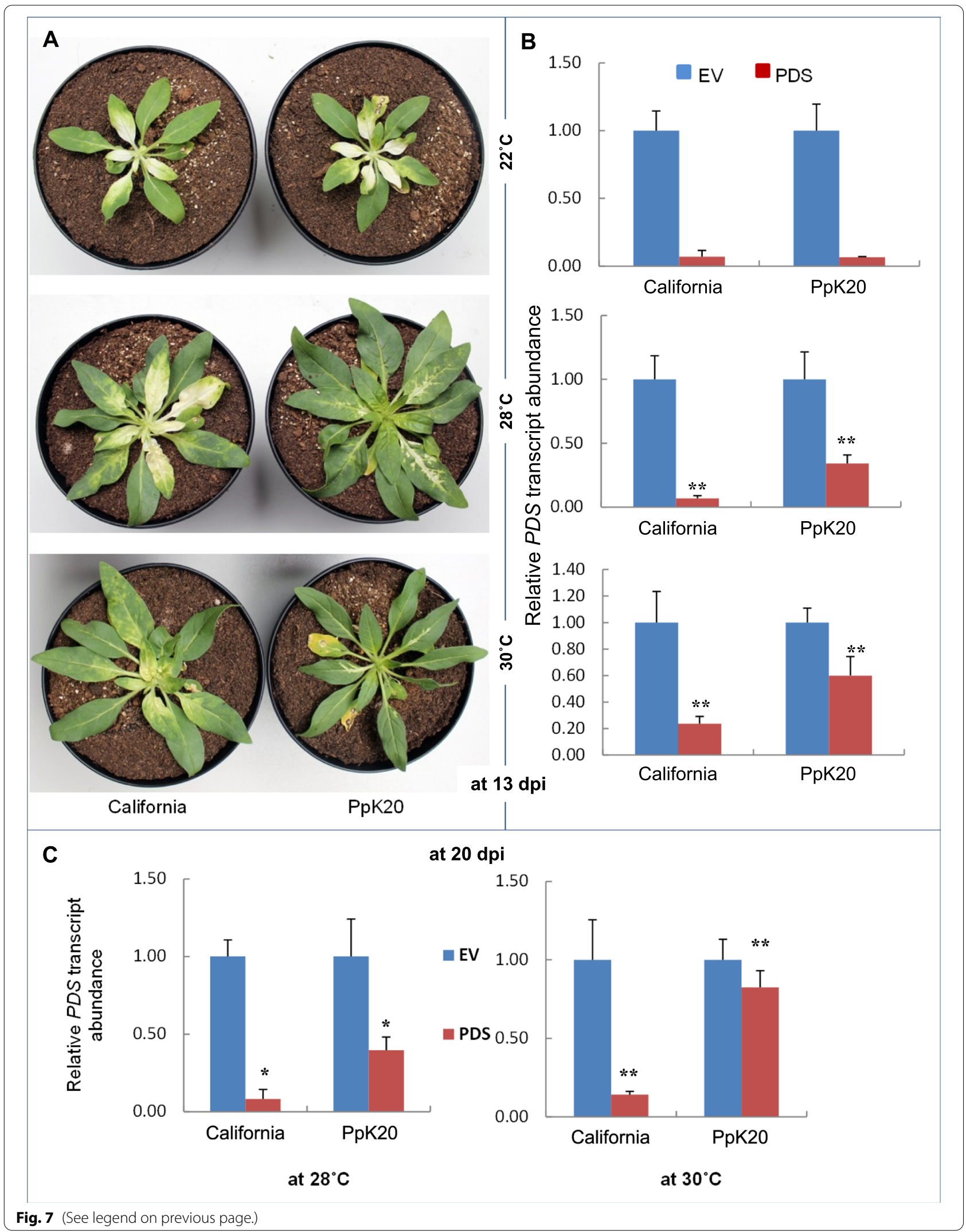



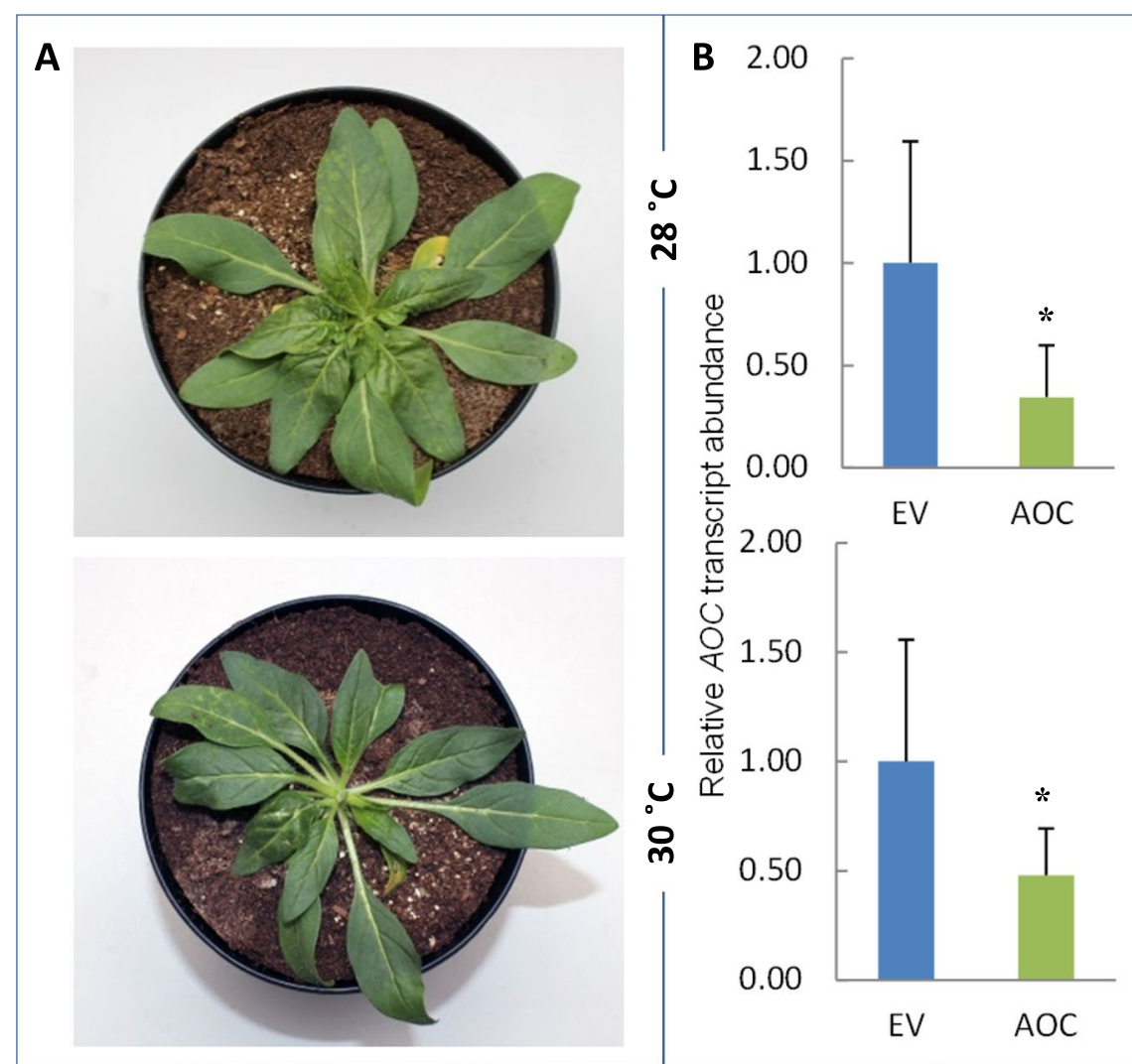

Fig. 8 Allene Oxide Cyclase (AOC) silencing induced by TRV California based VIGS vectors in N. attenuata. A Plants inoculated with TRV California based VIGS vectors (pTRV-RNA1/pTRV-RNA2:AOC) for AOC silencing. Pictures were taken at 13 dpi (days post inoculation). B Relative AOC transcript abundance in the same plants compared to empty vector controls. Growth temperatures after inoculation $\left(28^{\circ} \mathrm{C}\right.$ and $\left.30^{\circ} \mathrm{C}\right)$ are indicated. Apical leave samples for $A O C$ transcript quantification were taken at $13 \mathrm{dpi}$ and $5 \mathrm{~h}$ after treatment of the plants with Manduca sexta oral secretion (OS). Transcript abundance is shown as mean values \pm SD (Student's t-test, ${ }^{*} P<0.05$ )

induces gene silencing in $N$. attenuata at temperatures of up to $30^{\circ} \mathrm{C}$.

The origin and genome structure of different TRV strains are quite divergent. TRV virus is ubiquitous, found in Asia [41], Africa [42], Europe [30, 43] and America [12], demonstrating its wide range of adaptability. TRV has a bipartite RNA genome. In contrast to the relatively conserved genome organization of RNA1, the corresponding RNA2 genomes of different TRV isolates differ in length, genome organization and the RNA1related recombinant region [43]. Hernandez et al. (1996) [44] reported that the RNA2 composition of a tobravirus (TRV isolate PpK20) may change rapidly during serial passages through the host tobacco plant, while seven different RNA2 species were found to be associated with one RNA1 species in TRV infected Alstroemeria plants [13]. Here, the pair-wise alignment and phylogeny analysis of RNA1 genomes showed that the TRV California isolate has $93-94 \%$ identity with other TRV isolates reported from different regions of the world (Fig. 3A).
The phylogeny analysis shows that the European TRV isolate $\mathrm{PpK} 20$ is positioned in a separate clade of out-groups from the California isolates suggesting these isolates were evolved differently and are quite diverse (Fig. 3A). The RNA2 genome of TRV California isolate showed 97-99\% identity with RNA2 genomes of American and Asian TRV isolates, while the genome had $90-94 \%$ identity with RNA2 genomes the European TRV isolates indicating genomic diversity among RNA2 genomes (Fig. 3B). This result is consistent with previous reports that the RNA2 genome varies considerably among TRV isolates $[9,45]$. 99\% identity regarding genomic structures of both RNA1 and RNA2 is found between TRV California and a Michigan TRV, both isolates from the USA. These two isolates are placed in same clade of the phylogenic tree, suggesting these American isolates might have evolved from the same ancestors (Fig. 3A).

Among the different types of VIGS vectors, TRV-based vectors have proven the most effective ones because TRV has several distinct advantages over other viruses used for 
VIGS experimentations. The first TRV based VIGS vectors were developed by Ratcliff et al. (2001) [1], later on the vector system was modified by Liu et al. (2002) [16]. Both the vector systems are based on the TRV PpK20 isolate. Our new vectors based on the TRV California isolate differ from the previously reported pBINTRA6 and pTV00 vectors [1] in the sequences of the two viral genomes and in vector backbones. The pBINTRA6 vector based on the PpK20 isolate offers many advantages, but relatively low growth temperatures $\left(20^{\circ} \mathrm{C}\right.$ to $\left.22^{\circ} \mathrm{C}\right)$ are required for efficient and robust silencing [16]. Higher temperatures of $25^{\circ} \mathrm{C}$ and more completely prevent the formation of infectious virus particles. Therefore, in the pBINTRA6/pTV00 system at these temperatures gene silencing is abrogated in $N$. attenuata. In contrast, the new vectors based on TRV California successfully induce the gene silencing at higher growth temperatures (up to $30^{\circ} \mathrm{C}$ ) in N. attenuata (Figs. 5, 6 and 7). At a lower growth temperature $\left(22^{\circ} \mathrm{C}\right)$, both the PpK20 and TRV California derived vector systems induced profound $P D S$ silencing (Fig. 7). Increasing the growth temperature results in a strong reduction of silencing induced by the PpK20 system in $N$. attenuata, the PDS silencing efficiency is only about 67 and $40 \%$ at $28^{\circ} \mathrm{C}$ and $30^{\circ} \mathrm{C}$, respectively. In contrast, in plants inoculated with the TRV California vectors we found almost 90 and $79 \%$ PDS silencing at $28^{\circ} \mathrm{C}$ and $30^{\circ} \mathrm{C}$, respectively (Fig. $7 \mathrm{~A}$ and $\mathrm{B}$ ). In addition, the systemic spread of TRV California vector induced gene silencing reached into the newly emerged apical leaves at $28^{\circ} \mathrm{C}$ and $30^{\circ} \mathrm{C}$, while only very faint bleaching in the vein regions of older basal leaves was observed in plants inoculated with the PpK20 derived vectors (Fig. S4). From these results, we infer that the TRV California vectors are capable of inducing persistent gene silencing at growth temperatures up to $30^{\circ} \mathrm{C}$ in $N$. attenuata.

Our underlying assumption for developing a higher temperature tolerant VIGS vector system was that TRV isolates collected from places with higher annual average temperatures would allow VIGS at higher temperatures than those collected from lower temperature regions. The TRV PpK20 isolate, which is the origin of the viral elements on pBINTRA6 and pTV00, was collected from the soil of a potato farm in Kinshaldy, Scotland [30, 46] whereas the TRV California strain was collected from commercially grown spinach in coastal California (Santa Barbara County) [32]. Meteorological information on average temperatures of the geographic origins of these two TRV isolates reveals the expected differences. For example, the monthly average temperatures of Santa Barbara, CA, USA varies from $13^{\circ} \mathrm{C}$ in January to $22^{\circ} \mathrm{C}$ in September (Table S4), while the monthly average temperature of Scotland varies from $5^{\circ} \mathrm{C}$ in January to $16.6^{\circ} \mathrm{C}$ in August (Table S5). Thus, the different acclimatized temperatures of these two TRV isolates are consistent with the improved thermal tolerance of California VIGS vectors. However, this greater apparent thermal tolerance is associated with more severe growth stunting. Morphologically, the TRV California vectors inoculated plants showed greater growth retardation and feebler phenotypes than the plants inoculated with the PpK20 vectors (Fig. S4). These stronger viral phenotypes could be due to stronger virulence and pathogenicity traits. Genes of interest with expected phenotypes similar to these stronger viral phenotypes can clearly not be used for VIGS experiments with the TRV California vectors. The RNA1 and RNA2 vector swap experiments between the PpK20 and TRV California genomes (Fig. S5) suggested that mainly RNA1 determines the higher thermal tolerance of the TRV California vectors, but also RNA2 contributes to it.

The RNA1 genome of TRV contains the RdR polymerase, movement protein and suppressor protein. The virulence and pathogenicity of viruses are generally determined by RNAi suppressor proteins of viruses [47-49]. The suppressor proteins suppress the host RNA silencing defence mechanism and thus help the viruses to replicate and spread in their hosts [49-52]. We found significant differences between the sequences of the $16 \mathrm{kDa}$ suppressor proteins of the TRV California and PpK20 isolates. The pairwise alignment of both $16 \mathrm{kDa}$ suppressor proteins shows about $13 \%$ differences, while 1.7 and $2.4 \%$ variations are found between the two RdR polymerases and movement proteins, respectively (Figs. S6 and S7). We found about $44 \%$ differences between the coat proteins of TRV California and PpK20 (Fig. S7). Perhaps, the sequences differences in $16 \mathrm{kDa}, \mathrm{RdR}$ polymerase, movement proteins and coat proteins that evolved in TRV California are responsible for the higher virulence, but also for the higher and thermal tolerance of this virus.

\section{Conclusions}

The new VIGS vector system based on the TRV California isolate induces gene silencing in N. attenuata at temperatures of up to $30^{\circ} \mathrm{C}$. Gene silencing induced by TRV California vectors at these temperatures was more prominent and durable than silencing induced by the current TRV vector pBINTRA6/pTV00 system, suggesting that the new vector system is more thermal tolerant, but was associated with more pronounced growth defects. The greater thermal tolerance of the new vector system might be due to the sequence variations in suppressor protein, RdR polymerase and movement protein. The new vector system opens up an avenue to study genes functions in 
planta under field conditions and could be a revolutionary advance for ecological research.

\section{Methods \\ Tobacco rattle virus California strain}

The TRV California strain was collected by Hsing-Yeh Liu from commercially grown spinach (Spinacia oleracea) in coastal California (Santa Barbara County), California, USA [32]. The collected virus was then identified as TRV by electron microscopy and serological and molecular analyses [32]. The formal identification of the plant material used in our study was undertaken by Steven T. Koike, Tongyan Tian, and Hsing-Yeh Liu [32]. Spinach leaf samples infected with this virus were kindly provided by Dr. Bill Wintermantel, USDA-ARS, Salinas, CA, USA. No voucher specimen of this material has been deposited in a publicly available herbarium, but $-80^{\circ} \mathrm{C}$ frozen virus infected spinach leaf samples from this material are available upon request.

\section{Plant material and growth conditions}

The 31st inbred generation of the N. attenuata "Utah" ecotype, originally collected from a native population at a field site located in Utah (USA) was used in the experiments. Additionally, for the amplification of the TRV California isolate, healthy seedlings of spinach, pepper and $N$. benthamiana were used. Wild-type seeds of N. attenuata were surface sterilized and germinated on Gamborg's B5 medium (Duchefa, www.duche fa-biochemie.com) as previously described [53]. After 10 days the seedlings were carefully removed from the agar and transferred to soil in small Teku plastic pots (www.poeppelmann.com) in the glasshouse. Again, after 10 days in Teku pots, seedlings were transferred to $1 \mathrm{~L}$ pots in soil in a growth chamber. Growth chamber conditions were temperatures of $22^{\circ} \mathrm{C}, 26^{\circ} \mathrm{C}, 28^{\circ} \mathrm{C}$, $30^{\circ} \mathrm{C}$ and $32^{\circ} \mathrm{C}$, relative humidity of $65 \%$ and the duration of $16 / 8 \mathrm{~h}$ of day and night cycle and light intensity of $135-195 \mu \mathrm{Mols}^{-1} \mathrm{~m}^{-2}$ PAR.

\section{Bacterial strains, TRV PpK20 based vectors, enzymes and oligonucleotides}

For cloning and vector construction, chemically competent cells of E. coli TOP10 (Invitrogen, www.therm ofisher.com), and for plant transformation Agrobacterium tumefaciens GV3101 [containing plasmids pMP90 (pTiC58DT-DNA) and (as helper plasmid only with pTV00 derivatives) pJIC SA_Rep; kindly provided by the Sainsbury Laboratory, University of Cambridge, United Kingdom] were used.

The TRV PpK20 based vectors pBINTRA6, pTV00 and PTVPD [pTV00 carrying in its polylinker a
$206 \mathrm{bp} N$. benthamiana phytoene desaturase gene (pds) fragment in antisense orientation] were kindly provided by the laboratory of Sir David Baulcombe.

Antibiotics were obtained from Duchefa (www.duche fa-biochemie.com). Kanamycin $(50 \mathrm{mg} / \mathrm{L})$ was used for plasmid selection in $E$. coli TOP10. Kanamycin $(50 \mathrm{mg} / \mathrm{L})$ and rifampicin $(100 \mathrm{mg} / \mathrm{L})$ were the selective antibiotics for the A. tumefaciens GV3101 strains. SuperScript $^{\mathrm{TM}}$ III Reverse Transcriptase (Invitrogen, www.thermofisher.com) was the enzyme for cDNA synthesis. DNaseI (ThermoFisher Scientific, www.therm ofisher.com) was used for removing DNA contaminations from RNA preparations. Phusion High-Fidelity DNA Polymerase (ThermoFisher Scientific, www.therm ofisher.com) was the enzyme for polymerase chain reactions (PCR). Restriction enzymes were obtained from NEB (international.neb.com); T4-DNA ligase came from Invitrogen (www.thermofisher.com). All enzymes were used according to the instructions of the manufacturers. All oligonucleotides were synthesized by Sigma-Aldrich (sigmaaldrich.com).

\section{Amplification, isolation and sequencing of the TRV California genome}

We obtained the virus in dried spinach leaf samples. The host plant species, e.g. spinach, pepper, $N$. benthamiana and $N$. attenuata were inoculated with TRV California by rubbing Celite (diatomaceous earth; Sigma-Aldrich, www.sigmaaldrich.com) mixed with powdered infected spinach leaf samples or soaked with the extracted plant juice of previously infected plants, with fingers into the leaves of the healthy seedlings. The total RNAs of the plants showing typical symptoms of TRV infection were isolated from leaf samples using Trizol reagent (Invitrogen, www.thermofisher.com) according to the instructions of the manufacturer, followed by DNasel treatment, cDNA synthesis and PCR amplification. The primers for cDNA synthesis and PCR were designed from conserved sequences of full-length TRV-RNA1 and TRV-RNA2 genomes available in GenBank (Supplemental Table S1). First, the identity of the virus as TRV was confirmed by sequencing of a $341 \mathrm{bp}$ and a $611 \mathrm{bp}$ PCR fragment amplified from RNA1 cDNA. For this, cDNA was synthesized with an equimolar mixture of primers TRV40 and TRV45, followed by PCR with primer pairs TRV44/ TRV45, and TRV25/TRV26, respectively, and the synthesized cDNA as template. In the next step, the fulllength TRV California genomes were characterized. For this, the above described RNA1 cDNA and RNA2 cDNA synthesized with primer TRV52 were used. RNA1 and RNA2 genomes were then PCR-amplified with primer pairs TRV43/TRV40 and TRV51/TRV52, respectively. The full-length TRV RNA2 cDNA was cloned in the 
pCR Blunt II-TOPO vector (Invitrogen, www.therm ofisher.com), yielding pCR-RNA2. Cloning of the full length TRV RNA1 was not possible since one TRV RNA1 encoded protein (probably the RdR) is toxic to E. coli [1]. Therefore, the complete TRV RNA1 was amplified from the RNA1 cDNA as three fragments with overlapping sequences using primer pairs TRV43/TRV24, TRV46/ TRV47 and TRV44/TRV40. These fragments were subcloned in the pJET1.2 vector (ThermoFisher, www.therm ofisher.com). All cloned TRV cDNA sequences were Sanger sequenced on an Applied Biosystems 3130xl Genetic Analyzer. The primers used for cDNA synthesis, PCR and sequencing are listed in Supplemental Table S2.

\section{Construction of TRV California VIGS vectors}

To construct the new VIGS vectors, we used the backbone of plasmid pSOL9DEF1 (GenBank KF939593) and the cloned TRV California cDNA as PCR template. For the vector with the RNA1 cDNA, a series of consecutive cloning steps was performed: The $3^{\prime}$ terminal $1100 \mathrm{nt}$ of RNA1 containing the $16 \mathrm{kDa}$ protein ORF were amplified with primer pair TRV57/TRV58 and cloned as AseIBamHI fragment in pSOL9DEF1 (pTRV11). The adjacent $589 \mathrm{nt}$ of RNA1 were amplified with primer pair TRV59/ TRV60 and cloned as PstI-XhoI fragment (pTRV12). The next adjacent 2959 nt of RNA1 were amplified with primer pair TRV61/TRV60 and delivered as PstI-SacI fragment (pTRV13). The intron sequence of the A. thaliana NIA1 gene for nitrate reductase (Z19050) present on PBINTRA6 was amplified with primer pair TRV62/ TRV63, flanking RNA1 was added to the PCR fragment by PCR with primer pairs TRV64/TRV63 and then TRV65/TRV63 (template preceding PCR-fragments). The final intron fragment was cloned as BstEII-BglII fragment in RNA1 on pTRV13 to interrupt the ORF of the RdR and enable plasmid replication in E. coli (pTRV14). Further adjacent $242 \mathrm{nt}$ of RNA1 were amplified with primer pair TRV66/TRV67 and cloned as ApaI-XbaI-fragment in pTRV14 (pTRV15). The RNA1 sequence was completed by delivering the residual $5^{\prime} 1875 \mathrm{nt}$ of RNA1 as PCR fragment synthesized with primer pair TRV68/TRV69 and digested with PstI and ApaI to pTRV15 (pTRV16). The 35S terminator was PCR amplified from pSOL9DEF1 with primer pair TRV70/TRV71 and added as 210bp SnaBI-SpeI fragment to pTRV16 (TRV17). Finally, the $35 \mathrm{~S}$ promoter was PCR amplified from PSOL9DEF1 with primer pair TRV72/TRV73 and cloned as $601 \mathrm{bp} \mathrm{PmeI-}$ PstI fragment in pTRV17. The resulting VIGS vector was named pTRV-RNA1 and carries between CaMV35S promoter and terminator the full-length coding sequence of the TRV California RNA1 in sense orientation with an intron in the RdR ORF (14.4kb, Fig. 3A).
To construct the vector with TRV California RNA2 cDNA, in the first step the complete RNA1 on pTRVRNA1 was replaced with a polylinker followed by the $3^{\prime}$ $568 \mathrm{nt}$ of RNA2 in sense orientation. For this, the PCR fragment obtained with primer pair TRV74/TRV75 was cloned as PstI-XhoI fragment in pTRV-RNA1, yielding pTRV21. In the second step, the PCR fragment synthesized with primer pair TRV76/TRV77, comprising the $5^{\prime}$ $1161 \mathrm{nt}$ of RNA2 with the ORF of the coat protein was delivered as PstI-SalI fragment to pTRV21. The obtained VIGS vector pTRV-RNA2 (8.9kb, Fig. 3B) carried under the control of CaMV35S promoter and terminator the ORF of the TRV coat protein, directly downstream followed by a polylinker to facilitate cloning of target gene fragments. This polylinker was used to clone a $206 \mathrm{bp}$ PCR fragment of the phytoene desaturase (PDS) gene from $N$. benthamiana and a $258 \mathrm{bp}$ PCR fragment of the allene oxide cyclase $(A O C)$ gene from $N$. attenuata as $K p n I-S a c I$ fragments on pTRV-RNA2, yielding pTRVRNA2:PDS (9.1 kb) and pTRV:RNA2:AOC (9.2 kb). PCR was performed with primer pair PDS43/PDS44 on template pTVPD and with primer pair AOC7/AOC8 on cDNA from $N$. attenuata as template. The primers used for plasmid construction and sequencing are listed in Supplemental Table S2.

\section{VIGS inoculation of Nicotiana attenuata}

Agrobacterium tumefaciens GV3101 was transformed with plasmids pBINTRA6, pTV00, pTVPD, pTRVRNA1, pTRV-RNA2, pTRV-RNA2:PDS and pTRVRNA2:AOC. Leaves of 23-25 days old, healthy $N$. attenuata seedlings were co-inoculated with an A. tumefaciens GV3101 carrying a plasmid with TRV genome 1 (pBINTRA6 or pTRV-RNA1) and A. tumefaciens GV3101 carrying a plasmid with TRV genome 2 (pTV00, pTVPD, pTRV-RNA2, pTRV-RNA2:PDS or pTRVRNA2:AOC) using a $1 \mathrm{~mL}$ syringe without needle following the protocol described by Galis et al. (2013) [3]. For plant-juice inoculation, the juice was first extracted from the leaves of pre-established PDS silenced plants ( $N$. attenuata previously co-inoculated with $A$. tumefaciens GV3101 carrying pBINTRA6/pTVPD or pTRVRNA1/pTRV-RNA2:PDS). The extracted leave juice was then mixed with a tiny amount of Celite and young leaves of 23-25 days old, healthy plants were inoculated by rubbing. After inoculation, the plants were covered with an upside-down black tray and left in the dark for 2 days at $22^{\circ} \mathrm{C}$ to allow for $A$. tumefaciens proliferation and transformation. For the comparison of silencing efficiency of the two VIGS-vector systems (pBINTRA6/ pTV00 and pTRV-RNA1/pTRV-RNA2) at higher 
temperatures, inoculated plants were then transferred to growth chambers maintained at temperatures of $26^{\circ} \mathrm{C}$, $28^{\circ} \mathrm{C}, 30^{\circ} \mathrm{C}$ and $32^{\circ} \mathrm{C}$. At thirteen dpi (day post inoculation) apical leaf samples of inoculated plants were harvested for the determination of silencing efficiency of the target genes $P D S$ and $A O C$. All samples were collected in $2 \mathrm{~mL}$ Eppendorf tubes, flash frozen in liquid nitrogen and stored at $-80^{\circ} \mathrm{C}$ until analysis.

\section{Treatment of $N$. attenuata with oral secretion of Manduca sexta}

Manduca sexta oral secretion (OS) was collected on ice from larvae reared on $N$. attenuata plants until third to fifth instar as previously described [54]. For the induction of $A O C$ transcripts in plants inoculated with the pTRVRNA2:AOC and pTRV-RNA2 empty vector (EV) control constructs, at $13 \mathrm{dpi}$, one leaf per plant was wounded with a pattern wheel, and $20 \mu \mathrm{L}$ of 1:5 diluted OS of Manduca sexta were added to the puncture wounds. The apical leaves samples were harvested for quantification of $A O C$ transcripts $5 \mathrm{~h}$ after OS treatment.

\section{Quantitative PCR (qPCR) analysis}

Total RNA was isolated from leaf samples using Trizol reagent (Invitrogen, www.thermofisher.com) according to the instructions of the manufacturer, followed by DNaseI treatment. For cDNA preparation, $2 \mu \mathrm{g}$ of DNase-treated total RNA were used for first strand cDNA synthesis with an oligo $(\mathrm{dT})_{18}$ primer. For quantitative PCR analysis, four independent biological and three technical replicate samples were used for each treatment. Quantitative PCR analyses were performed on a Stratagene MX3005P (Agilent Technologies, www.agilent.com) using a qPCR Core Kit for SYBR Green I according to the instructions of the manufacturer (Eurogentec, www.eurogentec.com). The primers used for qPCR are listed in Supplemental Table S2. The elongation factor 1-alpha (EF1) gene (GenBank XM_019399807) was used for normalization.

\section{Sequence deposition in GenBank}

Sequence data of full-length genomes of TRV California RNA1 (MH614641) and RNA2 (MH614642) and the two VIGS vectors pTRV-RNA1 (MH625695) and pTRV-RNA2 (MH625696) are have been submitted to GenBank.

\footnotetext{
Abbreviations

AOC: Allene oxide cyclase; CaMV: Cauliflower Mosaic Virus; dpi: Days post inoculation; EF1: Elongation factor 1-alpha; EV: Empty vector; NCR: Non-coding regions; nt: Nucleotides; ORF: Open reading frame; OS: Oral secretion; PDS: Phytoene desaturase; RdR: RNA-dependent RNA polymerase; TRV: Tobacco Rattle Virus; VIGS: Virus-induced gene silencing; WT: Wild type.
}

\section{Supplementary Information}

The online version contains supplementary material available at https://doi. org/10.1186/s12870-021-03324-8.

\begin{abstract}
Additional file 1: Supplementary Table S1. GenBank accessions of full-length RNA1 and RNA2 genomes of different TRV isolates. Supplementary Table S2. List of primers used. Supplementary Table S3. Effect of different growth temperatures on PDS gene silencing in N. attenuata induced by TRV California VIGS vectors (pTRV-RNA1/pTRV-RNA2:PDS). Supplementary Table S4. Monthly temperatures in Santa Barbara, CA in 2009. Supplementary Table S5. Monthly average temperatures in Scotland 1971-2000. Supplementary file 2: Supplementary Figures. Supplementary figure S1. Disease symptoms in host plant species mechanically infected with TRV California. Supplementary figure S2. Detection of the TRV infection in host plants. Supplementary Figure S3. N. attenuata plants inoculated with the TRV California vector system, grown at different temperatures. Supplementary figure S4. Systemic silencing of the PDS gene in N. attenuata induced with the TRV California and PpK20 vectors after growth at $28^{\circ} \mathrm{C}$ and $30^{\circ} \mathrm{C}$ (sap inoculated). Supplementary figure S5. Swapping of RNA1 and RNA2 vectors of California and PpK20 isolates. Supplementary figure S6. ClustalW analysis of the RNA dependent RNA polymerase (RdR) proteins from the TRV California and TRV PpK20 isolates. Supplementary figure S7. ClustalW analysis of the $16 \mathrm{kDa}$ Suppressor proteins (A), Movement proteins (B) and Coat proteins (C) from the TRV California and TRV PpK20 isolates. Supplementary file 3: Original gel images of Fig. 1D, E, S2A and S2B with legends. Supplementary file 4: Original gel image file (JPEG format) Fig. 1D. Supplementary file 5: Original gel image file (JPEG format) Fig. 1E. Supplementary file 6: Original gel image file (JPEG format) Fig. S2A. Supplementary file 7: Original gel image file (JPEG format) Fig. S2B.
\end{abstract}

\section{Acknowledgements}

The work was supported by the Max Planck Society. JR was a Max Planck PostDoctoral Fellow. We thank Dr. Bill Wintermantel, USDA-ARS, Salinas, CA, USA for providing the TRV California virus infected plant samples.

\section{Authors' contributions}

J.R. performed all the experiments, analyzed the data and wrote the manuscript. J. R and K.G. designed the experiments. K.G. developed the strategy for the construction of the VIGS vectors and revised the manuscript. I.T.B. conceived of the thermal tolerance hypothesis, supervised the experiments and revised the manuscript. The author(s) read and approved the final manuscript.

Funding

Open Access funding enabled and organized by Projekt DEAL. The work was funded by the Max Planck Society, Germany.

\section{Availability of data and materials}

The authors declare that TRV California infected spinach leaf samples and the new VIGS vectors, TRV-RNA1 and TRV-RNA2, are available upon request.

\section{Declarations}

Ethics approval and consent to participate

This study does not include human or animal subjects.

Consent for publication

Not applicable.

Competing interests

The authors have no competing interest.

Author details

${ }^{1}$ Department of Molecular Ecology, Max Planck Institute for Chemical Ecology, Hans-Knoell-Str. 8, 07745 Jena, Germany. ${ }^{2}$ Present address: Department of Genetics and Plant Breeding, Sher-e-Bangla Agricultural University, Dhaka 1207, Bangladesh. 
Received: 18 August 2021 Accepted: 8 November 2021

Published online: 22 November 2021

\section{References}

1. Ratcliff F, Martin-Hernandez AM, Baulcombe DC. Technical advance. Tobacco rattle virus as a vector for analysis of gene function by silencing. Plant J. 2001;25(2):237-45.

2. Saedler R, Baldwin IT. Virus-induced gene silencing of jasmonateinduced direct defences, nicotine and trypsin proteinase-inhibitors in Nicotiana attenuata. J Exp Bot. 2004;55(395):151-7.

3. Galis I, Schuman MC, Gase K, Hettenhausen C, Hartl M, Dinh ST, et al. The use of VIGS technology to study plant-herbivore interactions. Methods Mol Biol. 2013;975:109-37.

4. Lu R, Martin-Hernandez AM, Peart JR, Malcuit I, Baulcombe DC. Virusinduced gene silencing in plants. Methods. 2003;30(4):296-303.

5. Burch-Smith TM, Anderson JC, Martin GB, Dinesh-Kumar SP. Applications and advantages of virus-induced gene silencing for gene function studies in plants. Plant J. 2004;39(5):734-46.

6. Senthil-Kumar M, Mysore KS. Tobacco rattle virus-based virusinduced gene silencing in Nicotiana benthamiana. Nat Protoc. 2014;9(7):1549-62.

7. Atamian HS. Virus induced gene silencing optimization in plants: things to be considered. J Postdoc Res. 2014;2:13-25.

8. Adams MJ, Heinze C, Jackson AO, Kreuze JF, Macfarlane SA, Torrance L. Family Virgaviridae. In: King AMQ, Adams MJ, Carstens EB, Lefkowitz EJ, editors. Virus taxonomy. Classification and nomenclature of viruses. Ninth Report of the International Committee on Taxonomy of Viruses. Waltham: Elsevier; 2012. p. 1139-62.

9. MacFarlane SA. Molecular biology of the tobraviruses. J Gen Virol. 1999;80:2799-807.

10. Ghazala W, Waltermann A, Pilot R, Winter S, Varrelmann M. Functional characterization and subcellular localization of the $16 \mathrm{~K}$ cysteine-rich suppressor of gene silencing protein of tobacco rattle virus. J Gen Virol. 2008;89:1748-58.

11. Hernández C, Visser PB, Brown DJ, Bol JF. Transmission of tobacco rattle virus isolate PpK20 by its nematode vector requires one of the two non-structural genes in the viral RNA 2. J Gen Virol. 1997;78:465-7.

12. Crosslin JM, Hamm PB, Kirk WW, Hammond RW. Complete genomic sequence of a tobacco rattle virus isolate from Michigan-grown potatoes. Arch Virol. 2010;155(4):621-5.

13. Koenig R, Lesemann DE, Pfeilstetter E, Winter S, Pleij CW. Deletions and recombinations with the RNA1 $3^{\prime}$ ends of different tobraviruses have created a multitude of tobacco rattle virus TCM-related RNA2 species in Alstroemeria and tulip. J Gen Virol. 2011;92:988-96.

14. MacFarlane SA. Natural recombination among plant virus genomes: evidence from tobraviruses. Seminars Virol. 1997;8:25-31.

15. Robinson DJ. Sequences at the ends of RNA-2 of I6, a recombinant tobravirus. Arch Virol Suppl. 1994;9:245-51.

16. Liu Y, Schiff M, Dinesh-Kumar SP. Virus-induced gene silencing in tomato. Plant J. 2002;31(6):777-86.

17. Jiang CZ, Chen JC, Reid M. Virus-induced gene silencing in ornamental plants. Methods Mol Biol. 2011;744:81-96.

18. Fullner KJ, Nester EW. Temperature affects the T-DNA transfer machinery of Agrobacterium tumefaciens. J Bacteriol. 1996;178(6):1498-504.

19. Fortier E, Belote JM. Temperature-dependent gene silencing by an expressed inverted repeat in Drosophila. Genesis. 2000;26(4):240-4.

20. Szittya G, Silhavy D, Molnár A, Havelda Z, Lovas A, Lakatos L, et al. Low temperature inhibits RNA silencing-mediated defence by the control of siRNA generation. EMBO J. 2003;22(3):633-40.

21. Bennypaul HS, Mutti JS, Rustgi S, Kumar N, Okubara PA, Gill KS. Virusinduced gene silencing (VIGS) of genes expressed in root, leaf, and meiotic tissues of wheat. Funct Integr Genomics. 2012;12(1):143-56.

22. Adelman ZN, Anderson MA, Wiley MR, Murreddu MG, Samuel GH, Morazzani EM, et al. Cooler temperatures destabilize RNA interference and increase susceptibility of disease vector mosquitoes to viral infection. PLoS Negl Trop Dis. 2013;7(5):e2239.

23. Zhong SH, Liu JZ, Jin H, Lin L, Li Q, Chen Y, et al. Warm temperatures induce transgenerational epigenetic release of RNA silencing by inhibiting siRNA biogenesis in Arabidopsis. Proc Natl Acad Sci U S A. 2013;110(22):9171-6.

24. Zhou $X$, Huang C. Virus-induced gene silencing using begomovirus satellite molecules. Methods Mol Biol. 2012;894:57-67.

25. Jupin I. A protocol for VIGS in Arabidopsis thaliana using a one-step TYMV-derived vector. Methods Mol Biol. 2013;975:197-210

26. Senthil-Kumar M, Mysore KS. Virus-induced gene silencing can persist for more than 2 years and also be transmitted to progeny seedlings in Nicotiana benthamiana and tomato. Plant Biotechnol J. 2011;9(7):797-806

27. Ryu CM, Anand A, Kang L, Mysore KS. Agrodrench: a novel and effective agroinoculation method for virus-induced gene silencing in roots and diverse Solanaceous species. Plant J. 2004;40(2):322-31.

28. Gao X, Shan L. Functional genomic analysis of cotton genes with agrobacterium-mediated virus-induced gene silencing. Methods Mol Biol. 2013;975:157-65.

29. Choi B, Kwon SJ, Kim MH, Choe S, Kwak HR, Kim MK, et al. A plant virusbased vector system for gene function studies in pepper. Plant Physiol. 2019;181(3):867-80

30. Ploeg AT, Brown DJF, Robinson DJ. The association between species of Trichodorus and Paratrichodorus vector nematodes and serotypes of tobacco rattle tobravirus. Annal Appl Biol. 1992;121:619-30.

31. Met Office UK. "Scotland 1971-2000 averages". 2001 https://web.archive. org/web/20040430030137/. http://www.metoffice.gov.uk/climate/uk/ averages/19712000/areal/scotland.html Accessed Aug 2020.

32. Koike ST, Tian T, Liu HY. First report of tobacco rattle virus in spinach in California. Plant Dis. 2010:94(1):125.

33. Hamilton WD, Boccara M, Robinson DJ, Baulcombe DC. The complete nucleotide sequence of tobacco rattle virus RNA-1. J Gen Virol. 1987;68:2563-75.

34. Sudarshana MR, Berger PH. Nucleotide sequence of both genomic RNAs of a north American tobacco rattle virus isolate. Arch Virol. 1998;143(8):1535-44.

35. Crosslin JM, Thomas PE, Hammond RW. Genetic variability of genomic RNA 2 of four tobacco rattle tobravirus isolates from potato fields in the northwestern United States. Virus Res. 2003:96(1-2):99-105.

36. Tamura K, Peterson D, Peterson N, Stecher G, Nei M, Kumar S. MEGA5: molecular evolutionary genetics analysis using maximum likelihood, evolutionary distance, and maximum parsimony methods. Mol Biol Evol. 2011:28(10):2731-9.

37. Gase K, Weinhold A, Bozorov T, Schuck S, Baldwin IT. Efficient screening of transgenic plant lines for ecological research. Mol Ecol Resour. 2011;11(5):890-902.

38. Wasternack C, Strnad M. Jasmonate signaling in plant stress responses and development - active and inactive compounds. New Biotechnol. 2016;33:604-13.

39. Kessler A, Halitschke R, Baldwin IT. Silencing the jasmonate cascade: induced plant defenses and insect populations. Science. 2004:305(5684):665-8.

40. Stenzel I, Hause B, Miersch O, Kurz T, Maucher H, Weichert H, et al. Jasmonate biosynthesis and the allene oxide cyclase family of Arabidopsis thaliana. Plant Mol Biol. 2003;51(6):895-911.

41. Shin HY, Koo BJ, Kang SG, Chang MU, Ryu KH. Characterization of tobacco rattle virus (TRV-K) isolated in Korea. Res Plant Dis. 2002;8:207-14.

42. Hamed AH, El-Banna M, Om-Hashem, Ghanem GA, El-Nagaar MH, Shafie MS. Isolation and identification of tobacco rattle tobravirus affecting onion (Allium cepa L.) plants in Egypt. Int J Virol. 2012;8(1):39-49.

43. Yin Z, Pawełkowicz M, Michalak K, Chrzanowska M, Zimnoch-Guzowska E. The genomic RNA1 and RNA2 sequences of the tobacco rattle virus isolates found in polish potato fields. Virus Res. 2014:185:110-3.

44. Hernandez C, Carette JE, Brown DJ, Bol JF. Serial passage of tobacco rattle virus under different selection conditions results in deletion of structural and nonstructural genes in RNA 2. J Virol. 1996;70(8):4933-40.

45. Macfarlane SA. Tobraviruses-plant pathogens and tools for biotechnology. Mol Plant Pathol. 2010;11(4):577-83.

46. Ploeg AT, Mathis A, Bol JF, Brown DJ, Robinson DJ. Susceptibility of transgenic tobacco plants expressing tobacco rattle virus coat protein to nematode-transmitted and mechanically inoculated tobacco rattle virus. J Gen Virol. 1993;74:2709-15.

47. Li F, Ding SW. Virus counterdefense: diverse strategies for evading the RNA-silencing immunity. Annu Rev Microbiol. 2006;60:503-31. 
48. Rahman J, Karjee S, Mukherjee SK. MYMIV-AC2, a geminiviral RNAi suppressor protein, has potential to increase the transgene expression. Appl Biochem Biotechnol. 2012;167(4):758-75.

49. Kumar V, Mishra SK, Rahman J, Taneja J, Sundaresan G, Mishra NS, et al. Mungbean yellow mosaic Indian virus encoded AC2 protein suppresses RNA silencing by inhibiting Arabidopsis RDR6 and AGO1 activities. Virology. 2015;486:158-72.

50. Rahman J, Mishra NS, Mukherjee SK. MYMIV-AC2 protein suppresses hairpin-induced gene silencing in Nicotiana tabacum cv. Xanthi Plant Biotechnol Rep. 2014;8:337-47.

51. Waterhouse PM, Wang MB, Lough T. Gene silencing as an adaptive defence against viruses. Nature. 2001;411(6839):834-42.

52. Buchon N, Vaury C. RNAi: a defensive RNA-silencing against viruses and transposable elements. Heredity (Edinb). 2006;96(2):195-202.
53. Krügel T, Lim M, Gase K, Halitschke R, Baldwin IT. Agrobacterium-mediated transformation of Nicotiana attenuata, a model ecological expression system. Chemoecology. 2002;12:177-83.

54. Halitschke R, Schittko U, Pohnert G, Boland W, Baldwin IT. Molecular interactions between the specialist herbivore Manduca sexta (Lepidoptera, Sphingidae) and its natural host Nicotiana attenuata. III. Fatty acid-amino acid conjugates in herbivore oral secretions are necessary and sufficient for herbivore-specific plant responses. Plant Physiol. 2001;125(2):711-7.

\section{Publisher's Note}

Springer Nature remains neutral with regard to jurisdictional claims in published maps and institutional affiliations.
Ready to submit your research? Choose BMC and benefit from:

- fast, convenient online submission

- thorough peer review by experienced researchers in your field

- rapid publication on acceptance

- support for research data, including large and complex data types

- gold Open Access which fosters wider collaboration and increased citations

- maximum visibility for your research: over $100 \mathrm{M}$ website views per year

At BMC, research is always in progress.

Learn more biomedcentral.com/submissions 